\title{
Spatial variability of air temperature in southern Brazil between 1961-2011
}

Flavia Venturini Rosso, Nathalie Tissot Boiaski and Simone Erotildes Teleginski Ferraz

flahvr@gmail.com; ntboiaski@gmail.com; simonetfe@gmail.com

Universidade Federal de Santa Maria

\begin{abstract}
Temperature is one of the most important variables used in climate studies. Changes in its time series can cause various social and political impacts, affecting diverse sectors of society, such as agriculture, for example. Southern Brazil is a region that relies heavily on agriculture, contributing to national production. Therefore, it is important to check the air temperature characteristic, i.e., its spatial pattern in this region. For this, daily data of minimum and maximum temperature of the air of the National Institute of Meteorology were used in the period from 1961 to 2011. The statistical technique of cluster analysis was applied to identify the homogeneous regions of temperature and the boxplot for the characterization of each one. In general, the results showed maximum values of temperatures in the west of Rio Grande do Sul. The regions of minimum temperatures presented a more homogenous pattern, with averages around $15{ }^{\circ} \mathrm{C}$. The regions of the maximum temperatures showed average values oscillating between $22{ }^{\circ} \mathrm{C}$ and $28^{\circ} \mathrm{C}$.
\end{abstract}

Keywords: Cluster Analysis. Temperature. Southern Brazil. 


\section{Introduction}

In several sectors of society, such as agriculture, commerce and tourism, knowledge of air temperature variability is very important for planning the activities of such sectors, allowing long-term decisions to be made from this knowledge.

The southern region of Brazil covers the states of Rio Grande do Sul, Santa Catarina and Paraná and is the smallest region of the country, with an area of $576.409 \mathrm{~km}^{2}$. In the field of economics, it is characterized by the great activity in several areas: in the primary sector, mainly in agriculture, it accounts for more than half of the grain production in Brazil; in the secondary sector, the textile and automotive industry predominates; the tertiary sector accounts for most of the region's income and employment generation.

According to the Instituto Brasileiro de Geografia e Estatística (IBGE), the southern region of Brazil led the national ranking of the production of grains, cereals, legumes and oilseeds, being responsible for about 60,3 million tons produced in 2011 (CANAL RURAL, 2011).

In one study, Cordeiro et al. (2016) using station data, observed a trend of increase in minimum and maximum air temperatures over Rio Grande do Sul from 1950 to 2009. In general, Rosso et al. (2015) also noted a significant positive trend in minimum and maximum air temperatures and a significant negative trend in the daily temperature range over southern Brazil between 1961 and 2011. Machado et al. (2010) using the cluster analysis technique found four homogeneous regions of precipitation and also temperature in the state of Rio Grande do Sul, and concluded that this method was satisfactory in the procedure of identification and separation of these regions, reproducing the physiographic and climatological conditions of State.

Changes in the temperature series, as well as their spatialization, can have a social and political impact, affecting the environment and the economy of a place. The south of Brazil is a region that depends heavily on agriculture and, therefore, it is important to contribute to the analysis of the climate of this region.

\section{Objectives}

Therefore, this work aims to investigate the spatial variability of minimum and maximum air temperatures in the southern region of Brazil between 1961 and 2011, through cluster analysis.

\section{Data and methodology}

For this study, daily data of minimum and maximum air temperatures of 28 meteorological stations of the southern region of Brazil were made available by the Instituto Nacional de Meteorologia (INMET) for the period 1961 to 2011 , totaling 51 years of data. No fault-filling method was applied in order to not mask the data and results, working with raw data, eliminating only the spurious values. Stations that had more than $25 \%$ of missing data were excluded from the work, resulting in 22 stations.

To determine the homogeneous regions, the multivariate statistical technique of the hierarchical grouping analysis was used, using the Euclidean distance as a grouping function. This cluster analysis aims to group elements of data based on their similarity, that is, is a process of partitioning a heterogeneous population into several more homogeneous subgroups, in order to obtain homogeneity within each group and heterogeneity between them. Thus, in a P-dimensional space, the distance between two points $\boldsymbol{x}_{\boldsymbol{i}}$ e $\boldsymbol{x}_{\boldsymbol{j}}$ is given by: 


$$
d_{i j}=\left\|x_{i}-x_{j}\right\|=\left[\sum_{k=1}^{P}\left(x_{i, k}-x_{j, k}\right)^{2}\right]^{\frac{1}{2}}
$$

The hierarchical grouping method used was that of the average linkage. According to Wilks (2006), this method defines the average distance between all possible pairs of points in the two groups to be compared. The choice by this method is due to its better functioning in relation to the grouping of regions and the lower noise sensitivity than the other methods. Finally, the dendrogram of the cluster analysis was generated, the demonstrative figure with the stations that were grouped and the boxplot of the homogeneous regions of the minimum and maximum temperatures. This dendogram is a two-dimensional diagram, where each branch represents one element, while the root represents the grouping of all elements.

\section{Results and discussions}

Minimum temperature

From the dendrogram of the minimum temperature (Figure 1), with a "cut value" close to 200, six homogeneous regions were formed. São Joaquim (SC) was not grouped with any station, possibly due to the difference in altitude with the other stations (this station is located at 1400 meters above sea level).

Figure 2 shows the stations that were grouped: Region 1 (blue points) includes Uruguaiana and São Luiz Gonzaga, due to the effect of continental (more distant of the ocean) and the low altitudes of the stations, Region 2 (orange points): Encruzilhada do Sul, Bagé and Santa Vitória do Palmar, covering the south-central part of the RS, Region 3 (green points): Cruz Alta, Passo Fundo, Bento Gonçalves and Caxias do Sul, which are stations with higher altitudes, some of them located in the Sierra Gaúcha, Region 4 (yellow points): Torres, Porto Alegre and Rio Grande, located in the east of RS and near the coast, being under the influence of the Atlantic ocean, which acts as a thermal regulator, Region 5 (purple points): Campo Mourão, Castro and Curitiba, Region 6 (red points): Maringá, Londrina and Paranaguá, located in the north-northeast region of PR.

Thus, with the defined homogeneous regions one can characterize each one, according to Figure 3 . Region 1 presented an median temperature around $15^{\circ} \mathrm{C}$, with a maximum near $30^{\circ} \mathrm{C}$ (region with the highest maximum temperature value) and minimum $0^{\circ} \mathrm{C}$. Region $2 \mathrm{had}$ an median of $14^{\circ} \mathrm{C}$, maximum of $27^{\circ} \mathrm{C}$ and minimum of $-1{ }^{\circ} \mathrm{C}$ (region with the lowest minimum temperature value). The Region 3 showed a maximum of $25^{\circ} \mathrm{C}$ and a minimum of $1{ }^{\circ} \mathrm{C}$, with a median of $14^{\circ} \mathrm{C}$. In Region 4 during the study period, the maximum was $28^{\circ} \mathrm{C}$, the minimum of $2^{\circ} \mathrm{C}$ and the median of $16^{\circ} \mathrm{C}$. The homogeneous region 5 presented an median of $14^{\circ} \mathrm{C}$, with a maximum of $25^{\circ} \mathrm{C}$ and a minimum near $1^{\circ} \mathrm{C}$. Finally, Region 6 showed a maximum value of $28^{\circ} \mathrm{C}$, minimum of almost $7^{\circ} \mathrm{C}$ and median of $18^{\circ} \mathrm{C}$. 


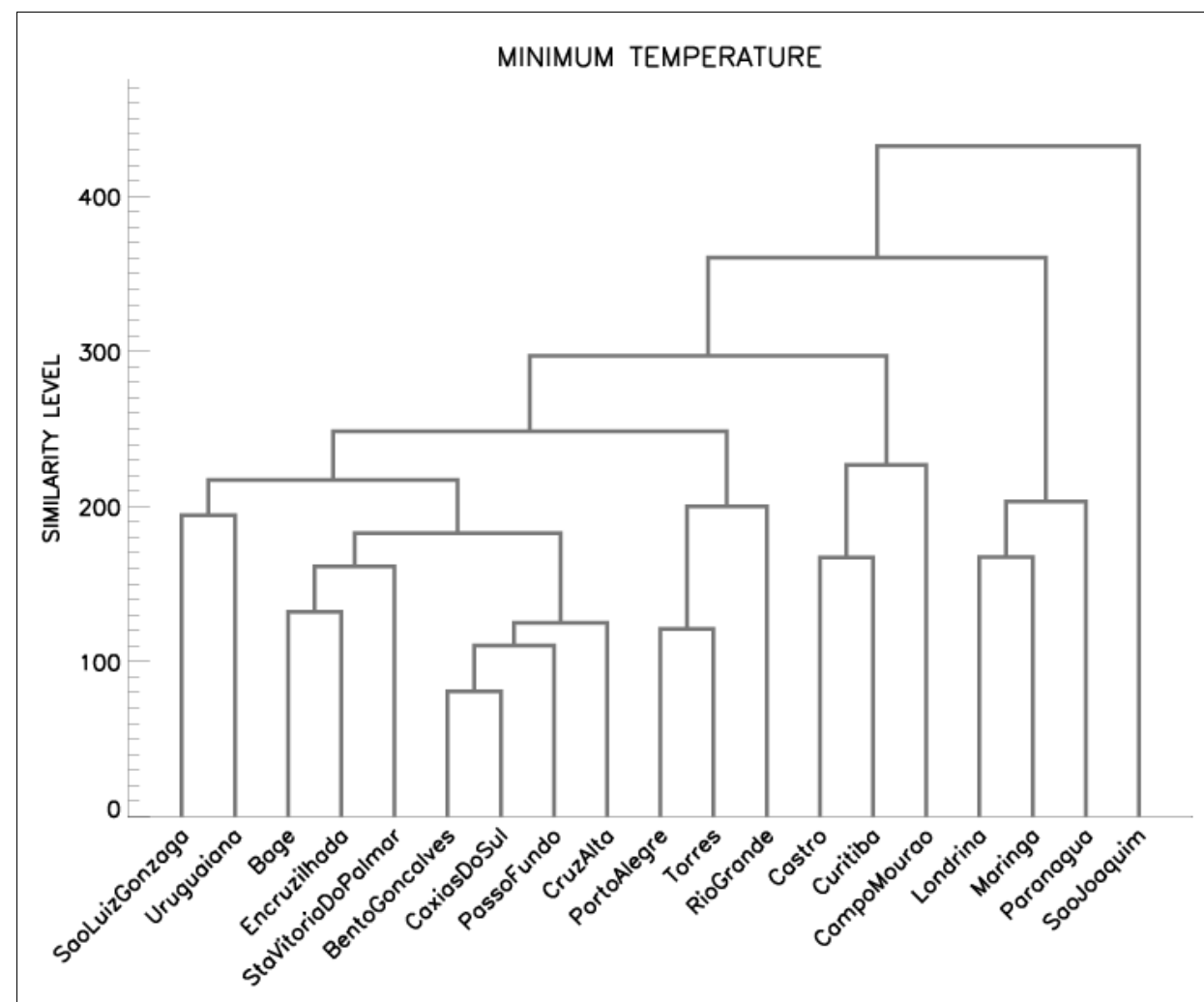

Figure 1 - Dendrogram of the cluster analysis of minimum air temperature at INMET stations in southern Brazil between 1961 and 2011

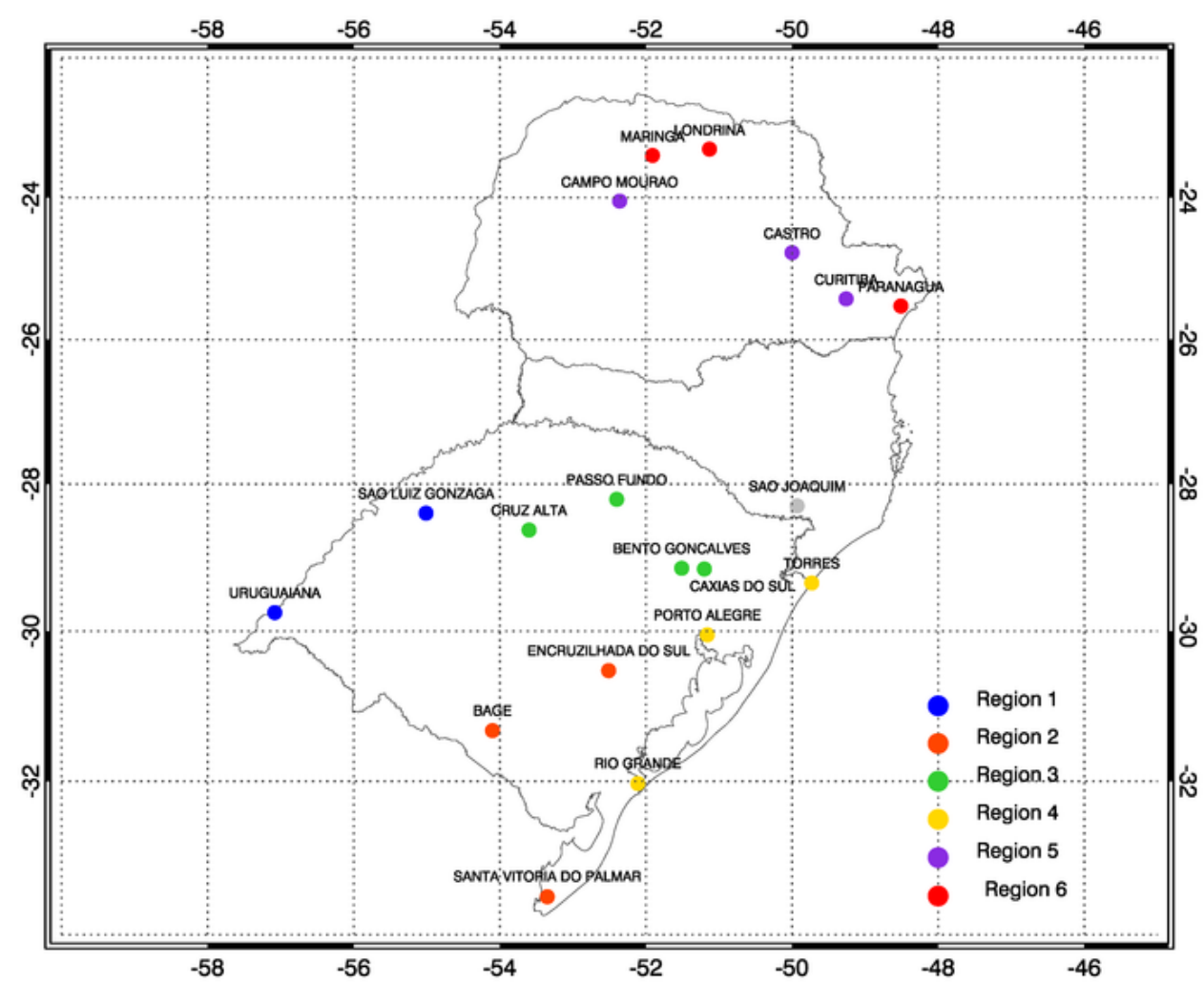

Figure 2 - Homogeneous regions of the minimum air temperature $\left({ }^{\circ} \mathrm{C}\right)$ in southern Brazil between 1961- 2011 


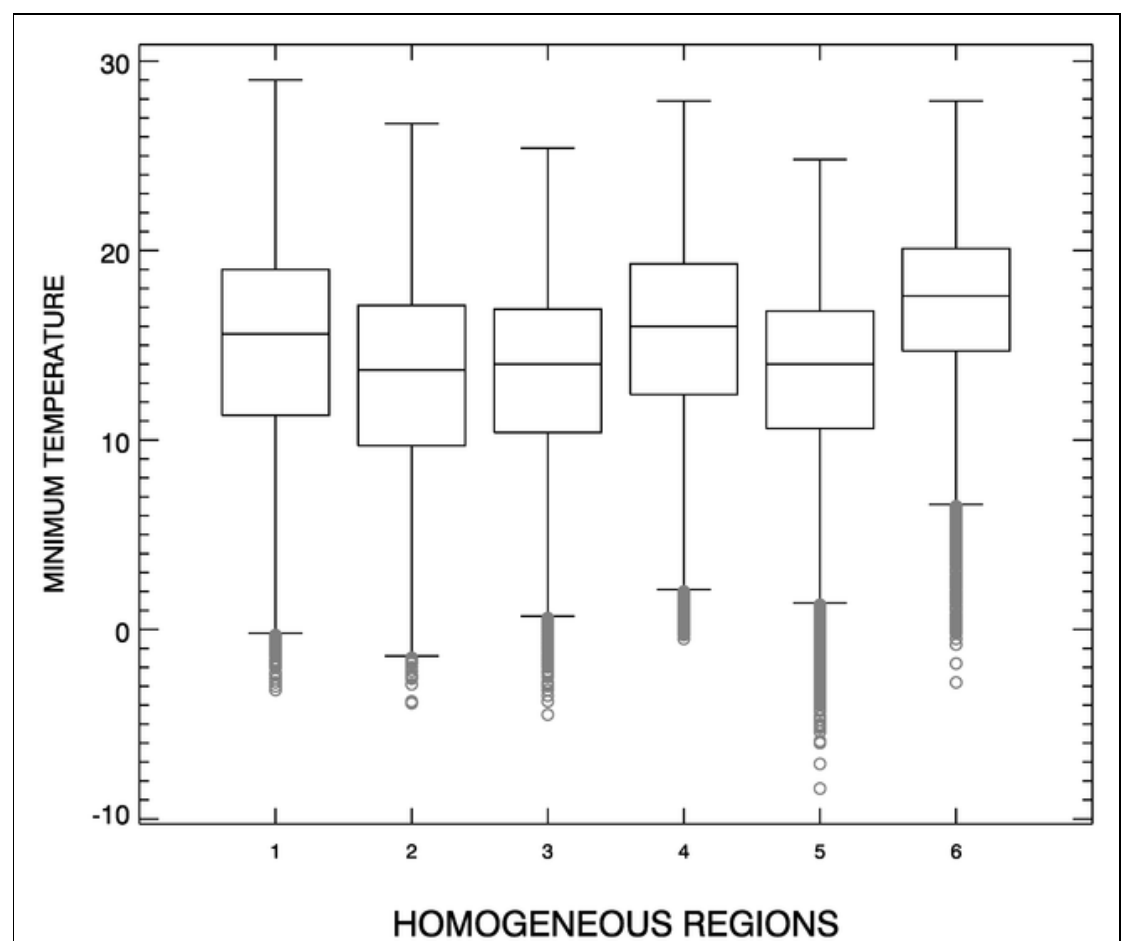

Figure 3 - Boxplot of the homogeneous regions of the minimum air temperature $\left({ }^{\circ} \mathrm{C}\right)$ in southern Brazil between 1961- 2011

\section{Maximum temperature}

Figure 4 shows the dendrogram of the maximum air temperature, through which five homogeneous regions were formed. Here again, the São Joaquim (SC) station was not grouped with any other.

The location of these homogeneous regions is shown in Figure 5 and is similar to the behavior of homogeneous regions of minimum temperature: Region 1 (blue points): Castro, Curitiba and Paranaguá, in the east of the PR, being under the influence of the ocean, Region 2 (red points): Campo Mourão and Londrina (north of PR), Region 3 (green points): Rio Grande, Torres and Santa Vitória do Palmar, in eastern RS and also under a maritime influence, Region 4 (yellow points): Cruz Alta, Passo Fundo, Porto Alegre, Bagé, Encruzilhada, Bento Gonçalves and Caxias do Sul, and finally the Region 5 (purple points) composed by São Luiz Gonzaga and Uruguaiana, which have low altitudes.

The characterization of each region can be done from the boxplot (Figure 6). In Region 1 the maximum temperature was $37^{\circ} \mathrm{C}$, the minimum was $12{ }^{\circ} \mathrm{C}$ and the median was approximately $25^{\circ} \mathrm{C}$. In 2 , a maximum value of $39^{\circ} \mathrm{C}$, minimum of $16^{\circ} \mathrm{C}$ and median of $28^{\circ} \mathrm{C}$ was observed. The Region 3 presented maximum temperature of $36^{\circ} \mathrm{C}$, minimum of $8^{\circ} \mathrm{C}$ and median of $22^{\circ} \mathrm{C}$. In Region 4 the maximum was $40^{\circ} \mathrm{C}$, the minimum of $7^{\circ} \mathrm{C}$ and a median of $24^{\circ} \mathrm{C}$. In the last Region 5, a maximum value of almost $41^{\circ} \mathrm{C}$ was observed, a minimum value of $9^{\circ} \mathrm{C}$ and a median of $26^{\circ} \mathrm{C}$. 


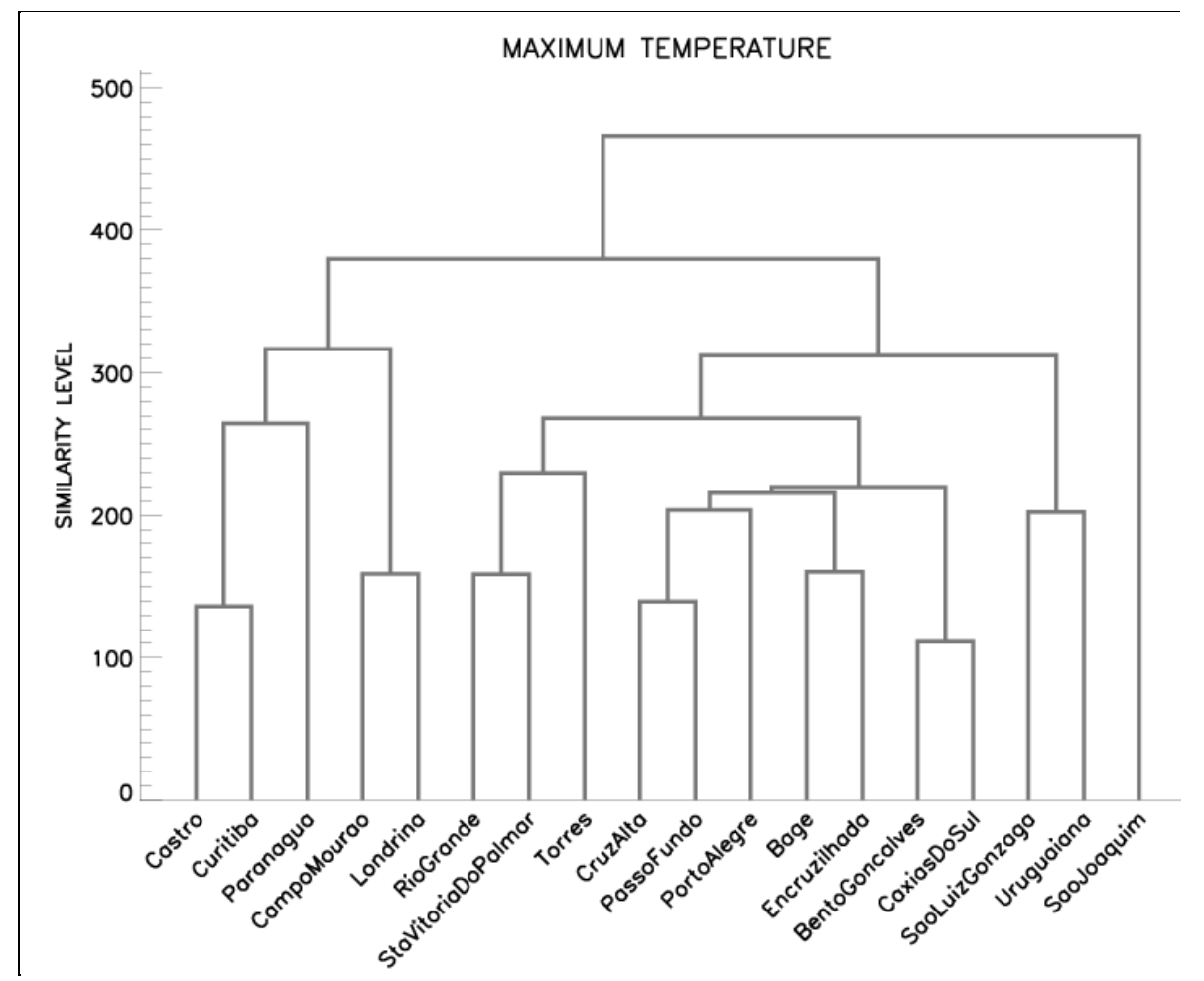

Figure 4 - Dendrogram of the cluster analysis of maximum air temperature at INMET stations in southern Brazil between 1961 and 2011

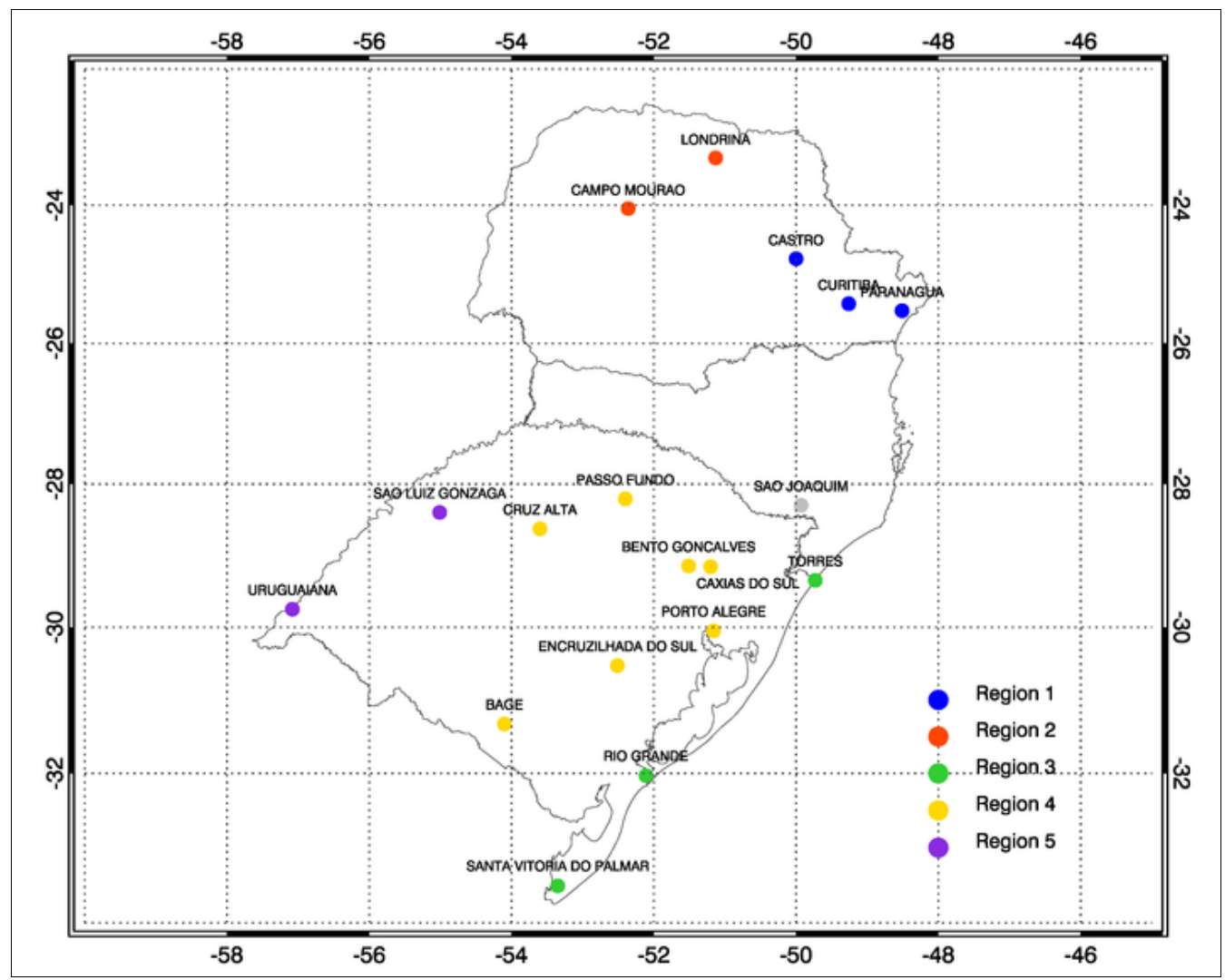

Figure 5 - Homogeneous regions of the maximum air temperature $\left({ }^{\circ} \mathrm{C}\right)$ in southern Brazil between $1961-2011$. 


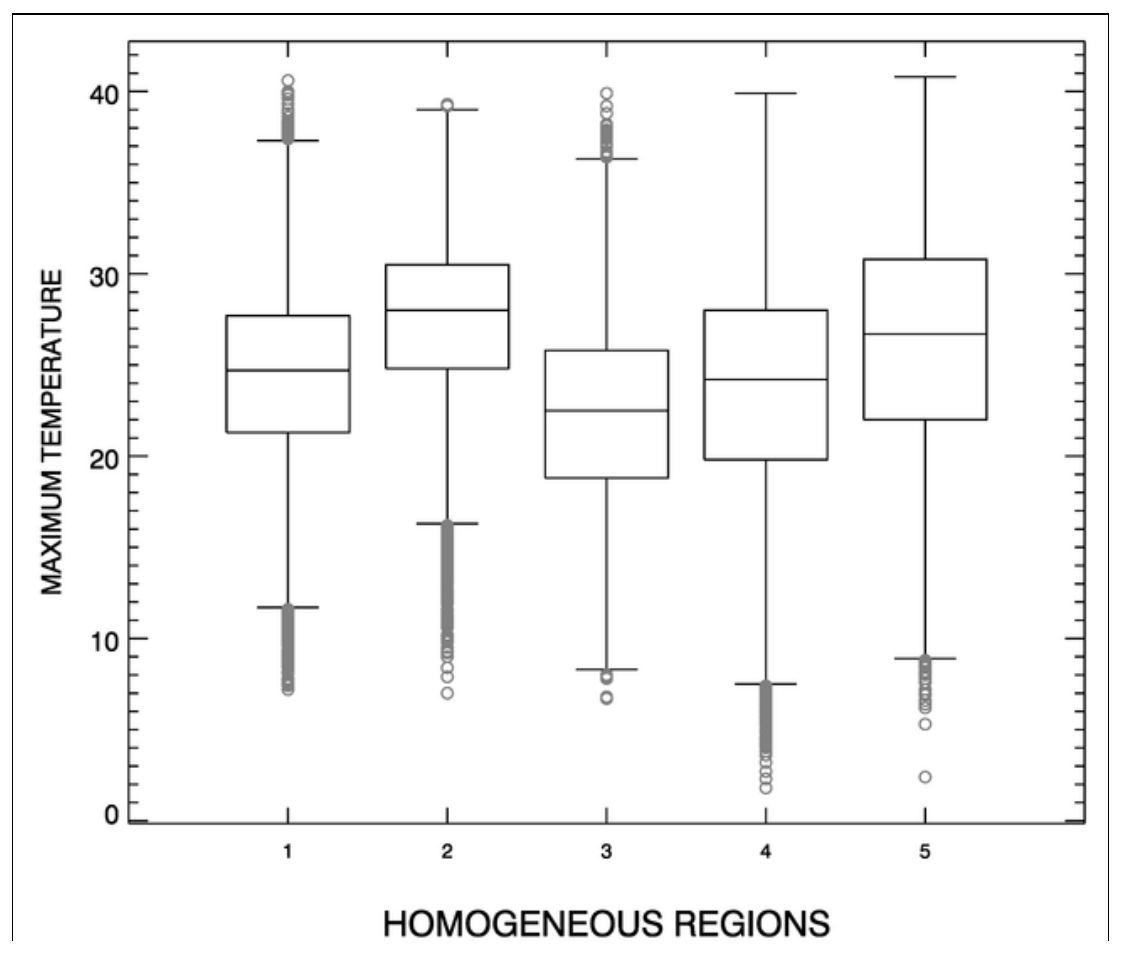

Figure 6 - Boxplot of the homogeneous regions of the maximum air temperature $\left({ }^{\circ} \mathrm{C}\right)$ in southern Brazil between 1961- 2011

\section{Conclusions}

In relation to the minimum temperature, all the regions presented a similar behavior regarding the median, with values around $15^{\circ} \mathrm{C}$. As for the maximum values, the regions showed a heterogeneous behavior, and the west of the state of Rio Grande do Sul (Region 1) showed the highest maximum value, reaching $30^{\circ} \mathrm{C}$. In general, the regions showed similarities in the minimum values, that is, they varied little from one to another, with temperatures around $0^{\circ} \mathrm{C}$; Only Region 6 showed a minimum value relatively higher than the others $\left(7^{\circ} \mathrm{C}\right)$, which is located to the north of the southern region of Brazil.

In the case of maximum temperature, a more heterogeneous pattern is observed. Maximum temperatures showed greater spatial variability than minimum temperatures. The maximum values ranged from $36^{\circ} \mathrm{C}$ to $41^{\circ} \mathrm{C}$, and the latter occurred in Region 5, which covers the stations in the west of Rio Grande do Sul. Minimum values ranged from $7^{\circ} \mathrm{C}$ (north-central Rio Grande do Sul) to $16^{\circ} \mathrm{C}$ (Northern Paraná). The median ranged from $22^{\circ} \mathrm{C}$ to $28^{\circ} \mathrm{C}$, with the highest average value in northern Paraná, which is closer to the tropics, and the lowest value in areas near the coast of Rio Grande do Sul.

The São Joaquim station in Santa Catarina was not grouped with any other and this may be associated with the fact that it has an altitude of approximately 1400 meters, very different from the other stations. The analysis used in this work showed the determinant influence of topography and latitudinal and longitudinal variations, as well as the oceanic component, on the homogeneous regions. Finally, these results may contribute to studies in other areas, such as, for agricultural planning and decision making, which are based on the local climate of a region, and even for the planning of sectors like commerce and tourism, which depend on the knowledge of temperature variability to develop their activities. 


\section{Referências}

CANAL RURAL. IBGE: região sul lidera produção de grãos no país. São Paulo, 2011. Available in: http://www.canalrural.com.br/noticias/agricultura/ibge-regiao-sul-lidera-producao-graos-pais-16898. Acess in: 13 mar. 2017.

CORDEIRO, A. P. A. et al. Tendências climáticas das temperaturas do ar no estado do Rio Grande do Sul, sul do Brasil. Revista Brasileira de Geografia Física. 2016;09: 868-880.

MACHADO, J. P. et al. Comportamento da precipitação e da temperatura no Rio Grande do Sul baseado na análise de agrupamento. Revista Ciência e Natura. 2010;32: 49-63.

ROSSO, F. V. et al. Trends and Decadal Variability in Air Temperature over Southern Brazil. American Journal of Environmental Engineering. 2015;5: 85-95.

WILKS, D. S. Statistical Methods in the Atmospheric Sciences. 3. ed. United States of America: Elsevier, 2011.676 p. 